\title{
Viroplasm and Large Virus-Like Particles in the Dinoflagellate Gymnodinium uberrimum
}

LINDA SICKO-GOAD ${ }^{* 1}$ and G. WALKER ${ }^{2}$

1 Great Lakes Research Division, The University of Michigan, Ann Arbor, and 2 Electron Microscopy Laboratory, Department of Biology, Eastern. Michigan University, Ypsilanti

\section{Summary}

Virus-like particles (VLPs) measuring $385 \pm 5 \mathrm{~nm}$ in diameter are described in the freshwater dinoflagellate Gymnodinium uberrimum. The VLPs are found in association with, and "budding" from a vesicular viroplasmic area. A similar viroplasm was also found in a chrysophycean alga, Mallomonas sp. collected from the same general area in Saginaw Bay of Lake Huron. The nature of these VLPs and their virogenic stroma, in these algae from the Laurentian Great Lakes are discussed in the present report.

Keywords: Alga; Dinoflagellate; Gymnodinium; Viroplasm; Virus-like particles.

\section{Introduction}

Numerous reports of viruses and virus-like particles (VLPs) in the blue-green algae have emerged since SAFFERMan and MorRIs' initial discovery in 1963. Dubbed "cyanophages" (PADAN et al. 1967, PADAN and SHILO 1973) they received intensive study due, in part, to their possible use in the biological control of blue-green algae. However, ultrastructural observations of viruses and VLPs in the eukaryotic algae have occurred only relatively recently (LEE 1971, Pickett-Heaps 1972, Toth and Wilce 1972, Mattox et al. 1972, Baker and Evans 1973, Chapman and Lang 1973, Swale and Belcher 1973, Markey 1974, Clutheroe and Evans 1974, Pearson and Norris 1974, GibBs et al. 1975, Billard et al. 1976, Hoffman and Stanker 1976, Pienaar 1976, Oliveira and Bisalputra 1978) following earlier suggestions of a "virus-like" lytic agent in the green alga Chlorella pyrenoidosa (ZAvarzinA and Protsenko 1958, Zavarzina 1961, Tikhonenko and Zavarzina 1966).

The vast majority of VLPs in the eukaryotic algae exhibit a pentagonal or hexagonal profile in sectioned material and, hence, are thought to be

* Correspondence and Reprints: Great Lakes Research Division, The University of Michigan, Ann Arbor, MI 48109, U.S.A. 
icosahedral in three dimensional morphology. In most instances, VLP studies have been limited to descriptive morphology and, therefore, the VLP designation appears appropriate. Recently, however, isolation and infectivity of algal VLPs has been accomplished (GibBs et al. 1975, Oliveira and BAsalputra 1978), which lends classical credence to the true viral nature of the VLPs. These particles range from $22 \mathrm{~nm}$ in Chrysochromulina mantoniae (MANTON and Leadbeater 1974) to $240 \mathrm{~nm}$ in the green alga Oedogonium (PickettHears 1972).

This paper presents the first report of VLPs in a dinoflagellate. The VLPs are considerably larger than any previously seen in the algae and they appear to emanate from a viroplasm unique to the algae.

\section{Materials and Methods}

Phytoplankton samples were collected in Saginaw Bay and fixed with glutaraldehyde and osmium as previously described (SICKO-GOAD et al. 1977).

\section{Results}

The VLPs observed in Gymnodinium uberrimum were found in several cells in the collection. No overall estimate of abundance of infected cells was made since this particular dinoflagellate was not a major component of the assemblage collected. However, the infected cells possessed common features. One of the most prominent features of these cells was the obvious lack of a nucleus in cells infected with VLPs. This phenomenon was substantiated by serial sections through a single cell. Hence, the particles appear to be located in an area of the cell superficially described as cytoplasm, although the region may, in fact, represent degenerated nucleoplasm.

The cells noted here appear in an advanced stage of infection as the cell volume is largely replaced with VLPs and virogenic stroma (viroplasm) (Fig. 1). VLPs were not noted within chloroplasts or mitochondria and, although free ribosomes are abundant, rough endoplasmic reticulum is rare. Conversely, Golgi is proliferated and is found surrounding the extensive viroplasm. VLPs can be observed contiguous with, and apparently budding from, the vesicular viroplasm (Fig. 2). Particles closely associated with viroplasm are less osmiophilic and differentiated than more distant VLPs. These "welldifferentiated" VLPs measure $385 \pm 5 \mathrm{~nm}$ in diameter, are either pentagonal or hexagonal in sectional view suggesting an icosahedral form, and the majority contain a dense, osmiophilic core, a nucleocapsid, and an outer capsid material. Their morphology indicates that the VLPs may be members of the adeno- or herpes virus family and, hence, would be intranuclear replicating (DNA) viruses.

A viroplasm not unlike that noted in Gymnodinium uberrimum was also present in the Chrysophyte Mallomonas sp. VLPs surround the virogenic 


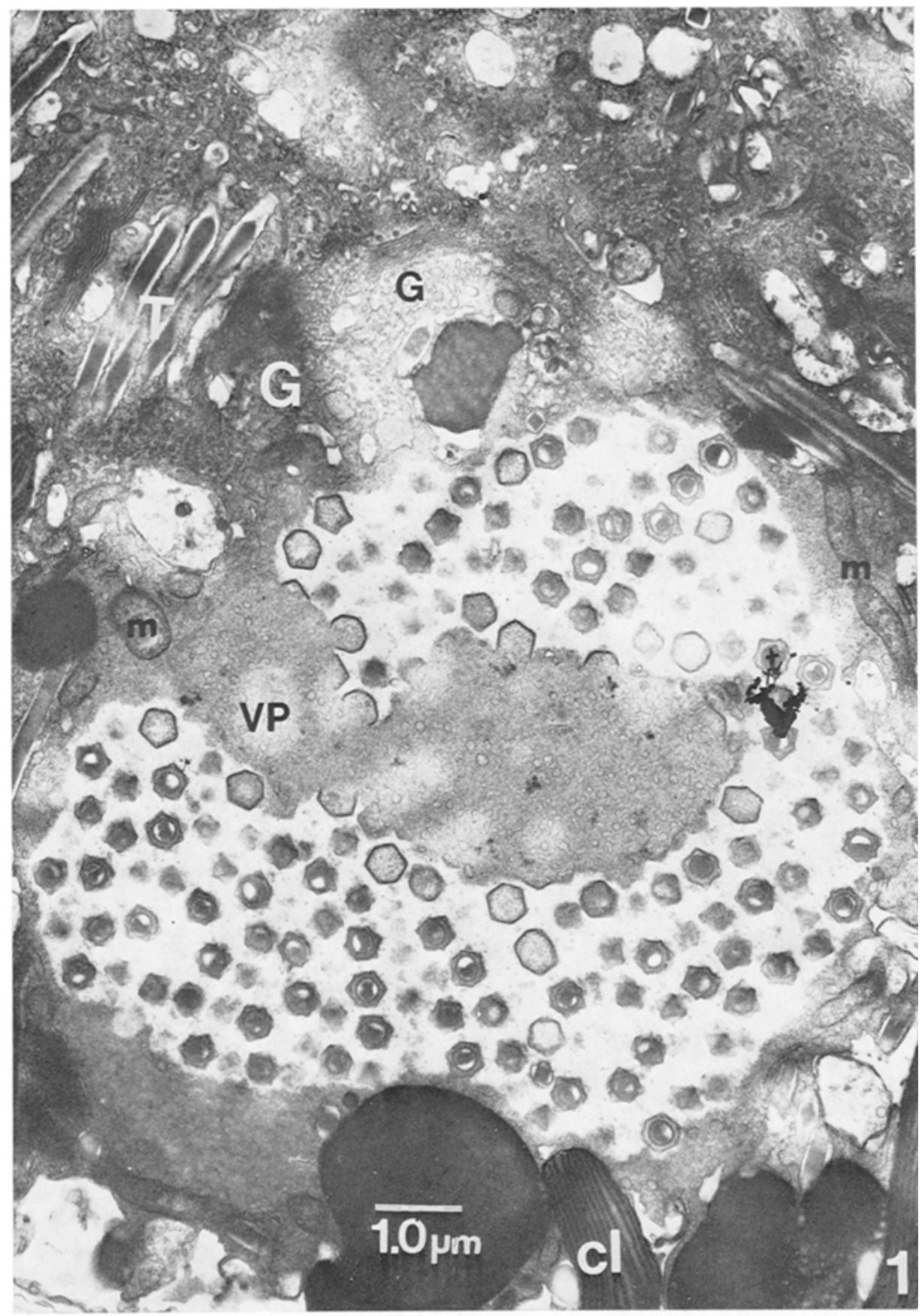

Fig. 1. Section through central portion of a cell of Gymnodinium uberrimum showing viroplasm $(V P)$ and extensive Golgi $(G)$ adjacent to this area. Chloroplast $(c l)$, trichocysts $(T)$, and mitochondria $(m)$ are also present. Lighter areas in the viroplasm are artifacts arising from holes in the formvar support 


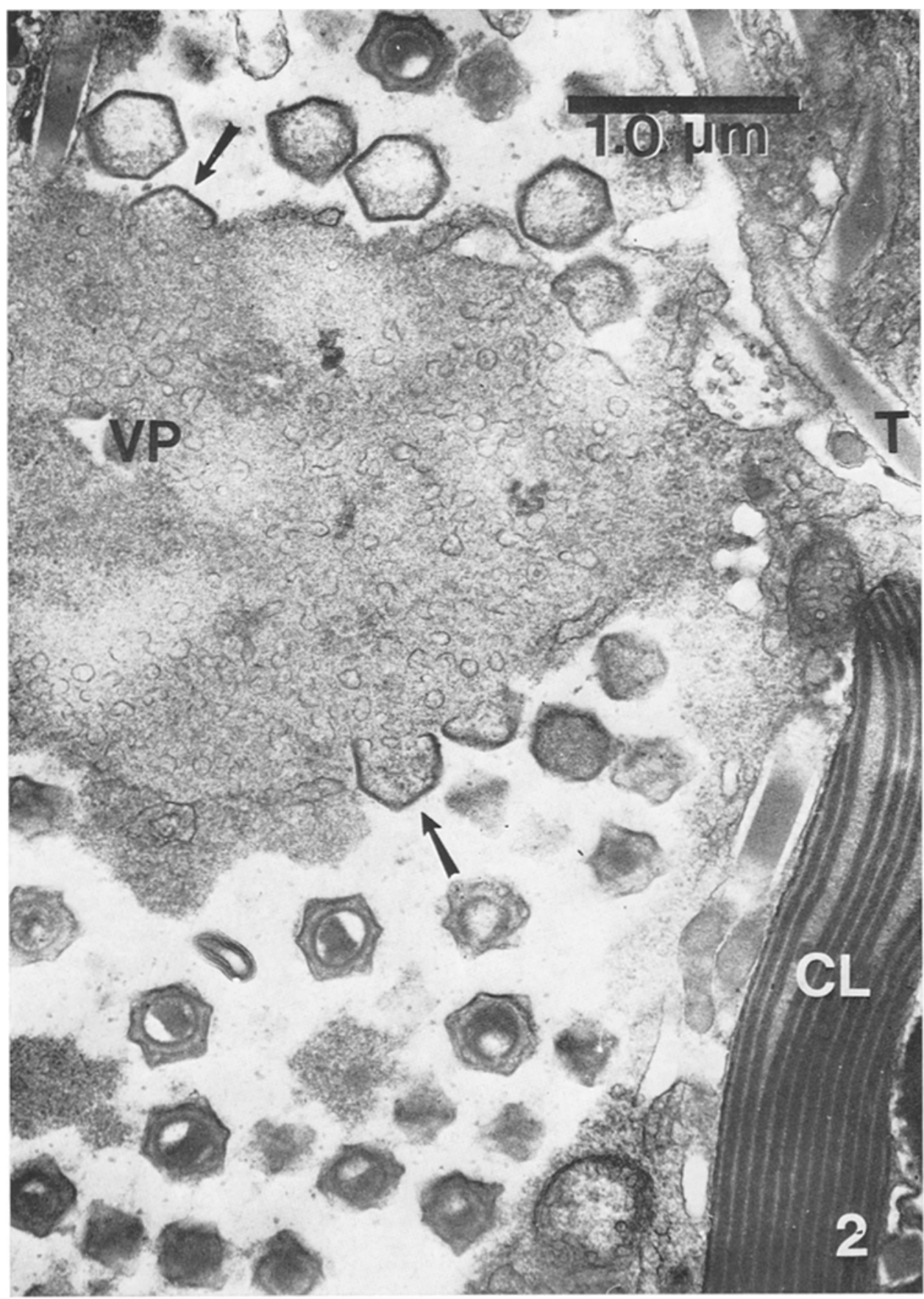

Fig. 2. Section through central portion of cell of Gymnodinium uberrimum showing vesicular virogenic stroma $(V P)$. Arrows point to areas where apparent "budding" is occurring. Other organelles labelled are chloroplast $(C L)$ and trichocysts $(T)$ 


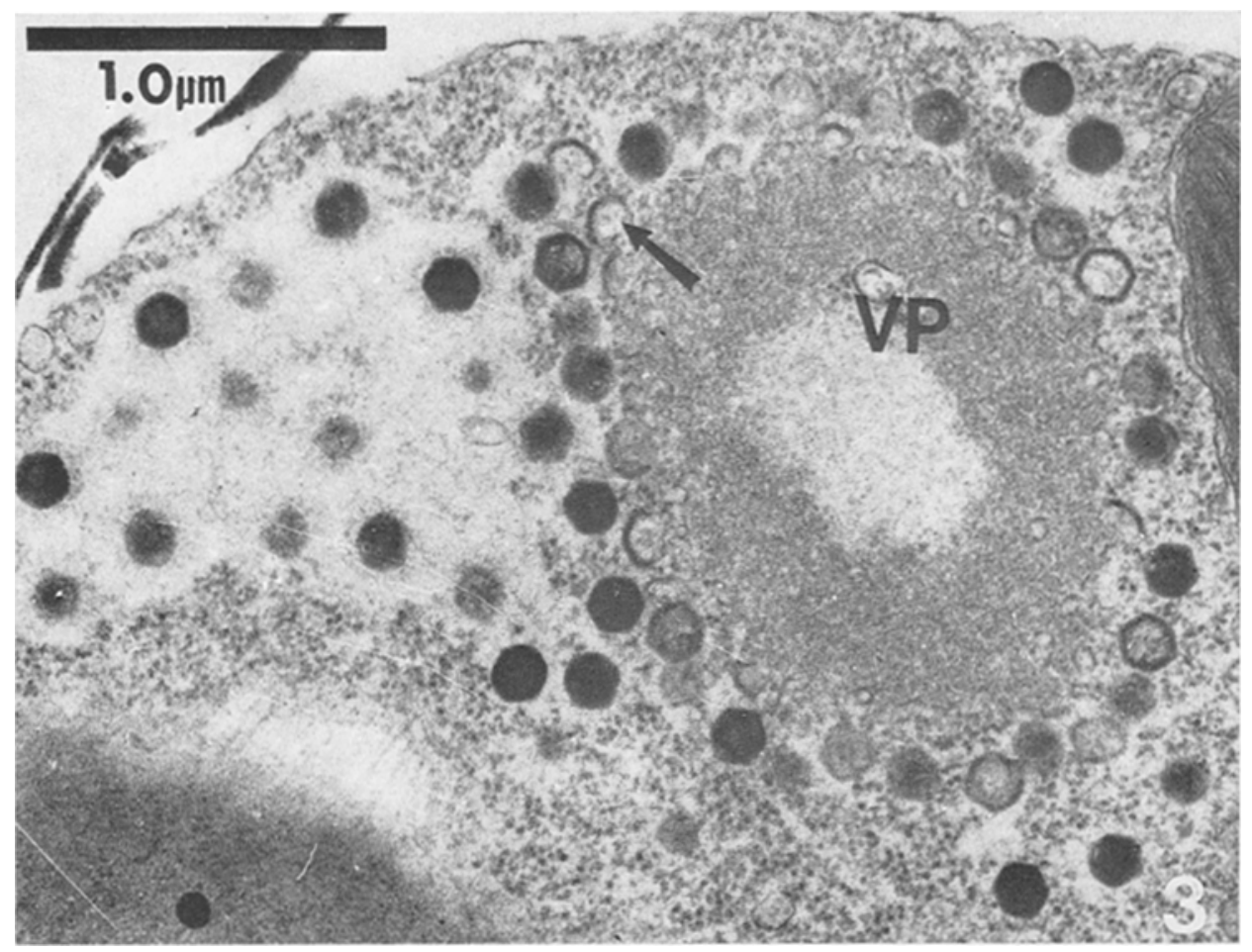

Fig. 3. Section through a chrysophycean alga, Mallomonas showing vesicular viroplasm (VP) and again, "budding" virus (arrow). Compare virus size in Figs. 1 and 2

stroma, are polyhedral (primarily hexagonal) in section and averaged $175 \pm 5 \mathrm{~nm}$ in diameter (Fig. 3). The cytoplasm does not appear significantly altered at this stage of infection.

\section{Discussion}

In 1963, DALES reported the coating of microtubules by viral specified material. Shortly thereafter (1965) he described sites within the host cell where viral materials might pool and where one might subsequently visualize stages in the "transformation of such materials into progeny virus particles". Since the advent of these early reports viral organizing centers or viroplasm have been noted in a wide range of host cells, including human cell cultures (HeINe et al. 1971), mouse fibroblasts (DAles et al. 1978), and eukaryotic algae (LEE 1971). BROWN et al. (1966) and SMITH et al. (1966) have described a "virogenic stroma" between the folded photosynthetic lamellae and the plasma membrane in the blue-green alga Plectonema.

In spite of the early report of LEE (1971), viroplasm has received little attention in the algae. We suggest, since viroplasm has been described for the red alga Sirodotia (LeE 1971), the green alga Cylindrocapsa (Hoffmann and 
Stanker 1976), the chrysophycean alga Hydrurus (Hoffmann 1978), suggested for the haptophyte Hymenomonas (PIENAar 1976), and described in this communication, that viroplasm is a common feature in the synthesis and/or assembly of algaphages. Evidence for the synthetic function of viroplasm has been collected for Shope fibroma virus infection of monkey kidney cells in culture, with the localization of ${ }^{3} \mathrm{H}$-Thymidine over foci of viroplasm (SCHERRER 1968). This suggests that the foci represent true sites of viral DNA replication, rather than accumulation areas for DNA synthesized elsewhere. Localization of ferritin labelled anti-virus antigens over viral heads in the virogenic stroma of Plectonema (SHERMAN and HASELKORN 1970) indicates that assembly of viral capsule also occurs within the viroplasm. These "viral factories" should be more evident in the eukaryotic algae with more intensive searching and experimental analysis.

The extensive Golgi network in Gymnodinium uberrimum associated with the viroplasm and VLPs suggests that membranes and other products of this complex may provide viral precursor material and participate in the process of VLP assembly. The Golgi apparatus has already been implicated in this process in the formation of Aura virus (Lascano et al. 1969). Furthermore, nerve cells infected with equine encephalomyelitis virus exhibit an increased number of Golgi complexes and depletion of polysomes (GARcia-TamaYo 1971); similar qualitative observations were made for Gymnodinium uberrimum in this report.

As noted by HofFman and STANker (1976), VLPs in the algae are frequently associated with degeneration of host cell organelles and eventual cell lysis. This provides strong inference that the particles truly are viral in nature. It also follows that, since no nucleus could be located in Gymnodinium uberrimum, the nucleus may have lysed early in the VLP infection. Nuclear lysis appears associated with the presence of VLPs in several other eukaryotic algae, including Pyramimonas (Møestrup and Thomsen 1974), Ectocarpus (Clitheroe and Evans 1974), Hydrurus and Cylindrocapsa (Hofrman and STANKER 1976). Since the VLPs in Gymnodium uberrimum do resemble a herpes or adenovirus, and these viruses have been shown to replicate within the nucleus (Harford et al. 1956, Morgan et al. 1959), the VLPS and viroplasm may, in fact, represent a degenerate nucleoplasm region.

The size of the VLPs in Gymnodinium uberimum is remarkable. They are significantly larger-by over $100 \mathrm{~nm}$-than any icosahedral VLPs reported thus far in the algae.

The discovery of these VLPs in dinoflagellates-and in the Great Lakes in general--raises some interesting questions and possibilities. For example, could the VLPs noted here represent a latent viral infection induced by changing environmental conditions? By fixing the cells at the collection site we know that this infection does occur in nature and was not induced by a laboratory environment. Further, HOFFMAN and STANKER (1976) have presented evidence 
which suggests that cultures of the green alga Cylindrocapsa may be carrying a latent virus infection which can be induced by heat shock. VLP occurrence in algae may eventually provide indications of a subtly changing aquatic environment.

Also, cognizant of the role of dinoflagellates in the production of a "red tide" and the present discovery of VLPs in a dinoflagellate (although, a fresh water dinoflagellate) one can envision the eventual possibility of a unique biological control mechanism for dinoflagellate blooms.

\section{Acknowledgements}

We wish to thank Dr. Wirliam Murphy for helpful discussion and Dr. E. F. Stoermer for identification of the dinoflagellate. This work was supported by grants R 805146020 and R 805796-01 from the Environmental Protection Agency, and an Eastern Michigan University faculty research grant. Great Lakes Research Division Contribution number 246.

\section{References}

Baker, J. R. J., Evans, L. V., 1973: The ship fouling alga Ectocarpus, I. Ultrastructure and cytochemistry of plurilocular reproductive stages. Protoplasma 77, 1-13.

Billard, C., Fresnel, J., Gayral, P., 1976: Particles virales intracytoplasmiques chez deux algues unicellulaires du nanoplancton marin. J. Microscopie Biol. Cell. 27, 3 A.

Brown, R. M., JR., SMITH, K. M., WALNE, P. L., 1966: Replication cycle of the blue-green algal virus LPP-1. Nature (London) 212, 729-730.

Chapman, R. L., Lang, N. J., 1973: Virus-like particles and nuclear inclusions in the red alga Porphyridium purpureum (Bory) Drew et Ross. J. Phycol. 9, 117-122.

Clitheroe, S. B., Evans, L. V., 1974: Virus-like particles in the brown alga Ectocarpus. J. Ultrastruct. Res. 49, 211-217.

Dales, S., 1963: Association between the spindle apparatus and reovirus. Proc. Nat. Acad. Sci. 50, 268-275.

- 1965: Replication of animal viruses as studied by electron microscopy. Am. J. Med. 38, 699-715.

- Milovanovitch, V., Pogo, B. G. T., Weintraub, S. B., Huima, T., Wilton, S., McFAdDEN, G., 1978: Biogenesis of vaccina: Isolation of conditional lethal mutants and electron microscopic characterization of their phenotypically expressed defects. Virology 84, 403-428.

Garcia-TAmayo, J., 1971: Acid phosphatase activity in mouse brain infected with venezuelan equine encephalomyelitis virus. J. Virol. 8, 232-241.

Gibbs, A., Skotnicki, A. H., Gardiner, J. E., Walker, E. S., Hollings, M., 1975 : A tobamovirus of a green alga. Virology 64, 571-574.

Harford, C. G., Hamlin, A., Parker, E., van Ravenswaay, T., 1956: Electron microscopy of HeLa cells infected with adenoviruses. J. exp. Med. 104, 443-454.

Heine, U., Ablashi, D. V., Armstrong, G. R., 1971: Morphological studies in Herpesvirus saimiri in Subhuman and human cell cultures. Cancer Res. 31, 1019-1029.

Hoffman, L. R., 1978: Virus-like particles in Hydrurus (Chrysopbyceae). J. Phycol. 14, $110-114$.

- Stanker, L. H., 1976: Virus-like particles in the green alga Cylindrocapsa. Can. J. Bot. 54, 2827-2841.

Lascano, E. F., Berria, M. I., Barrera-Oro, J. G., 1969: Morphogenesis of Aura Virus. J. Virol. 4, 271-282. 
LeE, R. E., 1971: Systemic viral material in the cells of the freshwater red alga Sirodotia tenuissima (Holden) Skuja. J. Cell Sci. 8, 623-631.

Manton, I., Leadbeater, B. S. C., 1974: Finestructural observations on six species of Chrysochromulina from wild Danish marine nanoplankton, including a description of C. campanulifera sp. nov. and a preliminary summary of the nanoplankton as a whole. Dan. Vidensk. Sel. Biol. Skr. 20 (5), 1-26.

Markey, D. P., 1974: A possible virus infection in the brown alga Pylaiella littoralis. Protoplasma 80, 223-232.

Mattox, K. R., Steward, K. D., Floyd, G. L., 1972: Probable virus infections in four genera of green algae. Can. J. Microbiol. 18, 1620-1621.

Møestrup, O., Thomsen, H. A., 1974: An ultrastructural study of the flagellate Pyramimonas orientalis with particular emphasis on Golgi apparatus activity and the flagellar apparatus. Protoplasma 81, 247-269.

Morgan, C., Rose, H. M., Holden, M., Jones, E. P., 1959: Electron microscopic observations on the development of Herpes simplex virus. Am. J. Med. 110, 643-656.

Oliveira, L., Brsalputra, T., 1978: A virus infection in the brown alga Sorocarpus uvaeformis (Lyngbye) Pringsheim (Phaeopbyta, Ectocarpales). Ann. Bot. 42, 439-445.

PadAn, E., SHILO, M., 1973: Cyanophages-viruses attacking blue-green algae. Bact. Rev. 37, $343-370$.

- Kislev, N., 1967: Isolation of "cyanophages" from freshwater ponds and their interaction with Plectonema boryanum. Virology 32, 234-246.

Pearson, B. R., Norris, R. E., 1974: Intranuclear virus-like particles in the marine alga Platymonas sp. (Chlorophyta, Prasinophyceae). Phycologia 13, 5-9.

Pickett-Heaps, J. D., 1972: A possible virus infection in the green alga Oedogonium. J. Phycol. 8, 44-47.

PienaAr, R. N., 1976: Virus-like particles in three species of phytoplankton from San Juan Island, Washington. Phycologia 15, 185-190.

Safferman, R. S., Morris, M. E., 1963: Algal virus: isolation. Science 140, 679-680.

Scherrer, R., 1968: Viral and host deoxyribonucleic acid synthesis in shope fibroma virusinfected cells as studied by means of high resolution autoradiography. J. Virol. 2, $1418-1428$.

Sherman, L. A., Haselkorn, R., 1970: LPP-1 infection of the blue-green alga Plectonema boryanum. II. Electron microscopy. J. Virol. 6, 820-833.

Sicko-Goad, L., Stoemer, E. F., Ladewskr, B. G., 1977: A morphometric method for correcting phytoplankton cell volume estimates. Ptotoplasma 93, 147-163.

Smith, K. M., Brown, R. M., Jr., Goldstein, D. A., Walne, P. L., 1966: Culture methods for the blue-green alga Plectonema boryanum and its virus, with an electron microscope study of virus infected cells. Virology 28, 580-591.

SWALE, E. M. F., Belcher, J. H., 1973: A light and electron microscope study of the colourless flagellate Aulacomonas Skuja. Arch. Mikrobiol. 92, 91-103.

Tikhonenko, A. S., Zavarzina, N. B., 1966: Morphology of the lytic agent of Clorella pyrenoidosa. Mikrobiologiya 35, 850-852.

TOTH, R., WILCE, R. T., 1972: Virus-like particles in the marine alga Chorda tomentosa Lyngbye (Phaeopbycea). J. Phycol. 8, 126-130.

Zavarzina, N. B., 1961: A lytic agent in cultures of Chlorella pyrenoidosa Pringh. cultures. Dokl. Akad. Nauk. SSSR 137, 435-437.

- Protsenko, A. E., 1958: The lysis of Chlorella pyrenoidosa Pringh. cultures. Dokl. Akad. Nauk. SSSR 122, 936—939. 